\title{
The Death of American Studies
}

Simon J. Bronner

\section{(2) OpenEdition}

\section{Journals}

\section{Electronic version}

URL: https://journals.openedition.org/ejas/13053

DOI: 10.4000/ejas.13053

ISSN: 1991-9336

\section{Publisher}

European Association for American Studies

\section{Electronic reference}

Simon J. Bronner, "The Death of American Studies", European journal of American studies [Online], 13-2 | 2018, Online since 11 September 2019, connection on 08 July 2021. URL: http:// journals.openedition.org/ejas/13053 ; DOl: https://doi.org/10.4000/ejas.13053

This text was automatically generated on 8 July 2021

Creative Commons License 


\title{
The Death of American Studies
}

\author{
Simon J. Bronner
}

1 The admittedly provocative title of this paper spins off Richard M. Dorson's landmark pamphlet The Birth of American Studies published on the occasion of the American Revolution Bicentennial in 1976. The widely distributed 30-page tract is important for its early historical consideration of American Studies as an institutionalized branch of learning in academe. Dorson was a member in 1936 of what is often acknowledged as the first doctoral program in American Studies, the "History of American Civilization" program at Harvard University. ${ }^{1}$ Dorson used the opening of an international American Studies center in Warsaw to reflect on the roots of what was then a growing American Studies movement in the United States and abroad. As he reflected back on the first forty years of American Studies with the implication that it had reached maturity or mid-life, I extend his life course metaphor here with an assessment of the forty years since his declaration of an "apex" moment for American Studies.

2 I recall that pivotal moment well, since at the time I served as Dorson's editorial assistant and student at Indiana University, in addition to having just begun my involvement with American Studies (see Bronner 1982; Bronner 1998, 349-412). Dorson was proud of being present at the creation of American Studies and brought several of his fellow pioneer Americanists from Harvard to Indiana University, including Henry Nash Smith, Daniel Aaron, and Leo Marx. If as an historian he felt a need to establish a genesis for American Studies, as an academic visionary and program builder he encouraged new formulations of the subject and as a globally minded scholar was especially gleeful about its expansion abroad (see Abrahams 1989 on Dorson as an "Americanist").

3 To Dorson, the emergence of American Studies was not a natural consequence, as it had sometimes been presented, of nationalist intellectual forces in the United States swirling during the 1930s by students to depart from studying ancient European civilization as the center of world history. To be sure, he understood the impetus for the rise of the United States as a global industrial power in the early twentieth century on national studies. He also recalled the grip of Eurocentrism in his own education and the desire in his generation for appreciating American arts as well as contemporary 
experience (Dorson was born in 1916 in New York City, received his Ph.D. from Harvard in 1942, and died in 1981 in Bloomington, Indiana). He could also recount the national dialogue during the Great Depression on America's future as well as its past as one that transcended disciplinary boundaries. He credited above all, however, the combination of strong, innovative personalities at Harvard for driving American Studies forward. Although there were calls for integrating studies of the United States elsewhere at the time, the cachet of Harvard taking the lead was significant to the academic respectability of American Studies nationally. Dorson commended the intrepid spirit and humanistic vision of his Harvard professors for establishing a major intellectual movement directed toward the growth of a distinct hybrid discipline that would be focused on explaining the American experience. For him, and them, American Studies was not just an early formulation of area studies; it was a special way of analyzing American history and culture, especially at the grassroots, to explain American experience and modern identity.

Dorson named Harvard professors Perry Miller, F. O. Matthiesen, Ralph Barton Perry, Howard Mumford Jones, and Bernard DeVoto as parents of an academic child drawing on their multiple backgrounds to raise an intellectual prodigy. They left to their offspring the task of developing, in Dorson's words, "a new kind of looking glass for proper scrutiny" of American culture in a global context. The founders uncovered an American subject "worth looking at," Dorson reflected, and passed on to their progeny an identity of "Americanist" that differed from a historian, literary scholar, anthropologist, or philosopher. "Heroic scholars," Dorson called them, because they "enlarged the vision of the meaning of America," particularly by broadening what scholars studied to include folk and popular arts, ethnic and racial groups, and women and occupational groups (Dorson 1976a, 30). Together with his other heroes including his naming of an inspirational woman Constance Rourke from Vassar who wrote American Humor (1931), "They established American Studies as a humane branch of learning," Dorson declared (Dorson 1976b, 26, 30). Although it is difficult to assign a singular method and theory to them, much of their work was integrative in the sense of using history and culture to locate social patterns and persistent ideas. Following the lead of Perry Miller (1956), they often applied symbolic, psychological, and rhetorical analysis or "close readings" of texts for behavioral information that led to positing kinds of American identities and practices as they have changed through time and space (see Edwards 2016; Fuller 2006; Murphey 2001; Smith 1957; Tate 1973). Howard Mumford Jones, who had taught comparative literature, and Constance Rourke, who did her post-graduate studies in London and Paris, were particularly globally minded and concerned for European-American cultural interchange (Jones 1964; Jones 1979; Rourke 1942; Rubin 1980).

5 Dorson's life course metaphor broadcast in 1976 suggested that American Studies had reached intellectual maturity at 40 in a progressive upward slope and the family of American Studies had spread well beyond Harvard. In that trek away from home, "American Civilization" that Dorson studied at Harvard had given way to "American Studies" at leading doctoral programs at Yale, Minnesota, Texas, New Mexico, and Maryland, among others. By 1950, departments of American Studies had also been formed outside of the United States in the University of Manchester, England, and Tokyo University, Japan. In 1979, Gene Wise, not a Harvard man (received his Ph.D. from Syracuse in 1963), followed Dorson with a retrospective of what he called the "American Studies movement" for American Quarterly. In addition to noting the 
foundational significance of Harvard's program, Wise also chronicled the design of a course at Yale in 1931 on "American Thought and Civilization" by Stanley T. Williams and Ralph Henry Williams and American Civilization programs in 1936-1937 at George Washington University, Western Reserve University, Union College, and University of Pennsylvania (Wise 1979a, 415). He identified the movement's history as a "sequence of representative acts" or "paradigm dramas" that mark historical phases. Rather than view this sequence as one stage displacing the other, Wise (1979b) in the framework of intellectual historian Vernon Louis Parrington (1927) discerned in each phase a "transactional quality" with factions in dialogue with one another, often taking the form of heated debate. Thus, American Studies, he argued, grew out of contention rather than consensus. Indeed, it drew its strength from serving as an open forum in which ideas in tension could coalesce and approaches negotiated toward the mission of identifying and interpreting the Americanness of America. In this essay, I apply his approach of interpreting contentious moments as direction-setting trials, rather than mere markers on a timeline, of the movement.

If American Studies is a flexible social movement structured to invite challenges to it rather than a stable institution purposed to sustain itself, then the movement has the benefit potentially of changing with the times and embracing innovation as part of a new paradigm (see Kuhn 1970). Yet the same praxis of self-criticism can problematically lead to schism and even demise of the movement. American Studies leading up to the apex of 1976 differed from other disciplines by being issue or theme, rather than methodologically, oriented, and allowing for coalescence of different approaches and concerns. Movement leaders held the view of an American Studies concept that could serve as a stream of ideas rather than a pillar or doctrine. I argue in this essay that the forty-year period for American Studies after Dorson's "mid-life" speech was characterized by an organizational turn away from, or even "death" of, intellectual resolution and inclusion typical of the "Americanist." I hypothesize reasons for this turn related to tumult within the American Studies Association and suggest ways that the academic schism might lead to a new vibrant trajectory, an Americanist renaissance if you will, that leaves the early stage of a diffuse American Studies behind.

\section{American Studies Coming of Age}

7 An initial contentious "representative act," to use Gene Wise's term, was the naming of an interdisciplinary area study devoted to the United States and the associated identification of scholars who took it up. In the early years of the American Studies movement, the academics who predominated had their primary affiliations in departments of English and history, and the question arose whether American Studies could become a primary identity for students and scholars (Bassett 1975; Walker 1958). In this context, Dorson (1979) contributed to Wise's retrospective with an essay speculating that a basis for a separate academic identity, if not discipline, is the distinctive personality of the American Studies scholar. He observed that "What they shared was a sense of exhilaration at manifold expressions of America as a civilization" (Dorson 1979, 370). In an early allusion to America as empire, the rhetoric of civilization pointed to the kind of society that expanded, often taking in other cultures and integrating, or colonizing, them into a sense of the whole. Use of "civilization" joined American Studies to classical learning that had excluded the American subject 
and announced the lens through which it was viewed to be humanistic. In keeping with the idea that historically, civilizations proceeded from east (China and the Near East as "cradles of civilization" to west (particularly Greek and Roman civilizations and the idea of "classical" culture from them) the study of American civilization transitioned the scholarly emphasis on European (or Western) civilization to North America, which presumably succeeded Europe as the world's center. The term civilization suggested within the society cultural practices that became lasting, dominant, and pervasive in their ascendant spheres of influence.

European scholars wanting to include American literature and history in their purview for the most part shared the approach to "civilization." For example, the by-laws drafted in 1954 by the European Association of American Studies declared the organization's purpose of "furthering the studies in Europe of the Civilization of the United States of America" (Mead, Skard, and Wightman 1955, 5; emphasis added), although the title of the organization and much of the news it broadcast concerned "the field of American Studies," which sounded more open to multiple disciplinary concerns and approaches to contemporary culture (Skard 1955b, 4). Among the scholars contributing to the direction of the organization were Harvard Americanists Daniel Aaron, Daniel Boorstin, Kenneth Murdock, and Arthur Schlesinger. Perhaps trying to defuse the notion that the Americanists wanted to study the United States in isolation, the summary prepared by Sigmund Skard, professor of American literature at the University of Oslo, stated that most "of the topics were concerned with the European impact on America" (Skard 1955a, 11). Skard added that from a European viewpoint, though, more attention was needed on American influence on Europe and the agents or intermediaries for exerting that influence-culturally as well as politically and economically. Indeed, Skard quoted one anonymous scholar as writing, "the impact of European ideas and institutions on American civilization and culture has been fairly thoroughly studied," while according to Skard, "little has been done the other way" (Skard 1955a, 12). The driving question both ways, Skard declared, was "What is it that makes...American anything, American?" (Skard 1955a, 14).

9 Walther Fischer from Marburg reporting "The Establishment and the Aims of the 'German Society for American Studies' ('Deutsche Gesellschaft für Amerikastudien')” in the newsletter identified two main practical experiences in Germany of American Studies. One was American Studies as an extension of "English Studies" to students planning to be secondary school teachers. The other which he labeled an "American conception" of area studies was broader in its inclusion "besides humanistic concerns of language and literature, all the 'social sciences' such as history, economics, art, and philosophy" and their methodologies (Fischer 1955, 10). He traced interest in an area study devoted to the United States to the first "Amerika-Institut" founded in Berlin in 1910, decades before Dorson's announcement of birth for the field in 1936 (see Fluck 2016). He hoped for a "real integration, a synthesis on the highest level of scholarship" of the two trends in American Studies in Germany to appeal to a wide array of students planning on professions beyond English teaching such as lawyers, economists, and journalists for a new Europe. He suggested Amerikastudien as a translation of American Studies in the big-tent approach of American Studies initiated in the United States, although writing in German, he referred to Amerikanistik (Americanistics) as a more focused and objective social scientific area study to separate from the pre-war use of Amerika-kunde with its suggestion of the National Socialist use of Volkskunde and 
inaugurate, in his words, "a new phase of American Studies" led by Americanists (Fischer 1955, 8; see also Fischer 1951; Fluck 2016; Strunz 1999, 241-42).

Following up on his Warsaw address, Dorson identified the doctoral children of Harvard's founding figures representing that "Americanist" type: Henry Nash Smith, Daniel Aaron, Edmund S. Morgan, and Frederick B. Tolles. Yet there was bound to be a lag in their ability to implement their integrative Americanist vision because the number of American Studies programs was small. Dorson, for example, had multiple appointments at Indiana University in American Studies, history, and folklore, but he predicted that the second generation of Americanists would increasingly lodge within American Studies programs. He liked the Americanist label to refer to someone who is analytical in approaching the society and culture of the United States as well as advocating for the field of study.

Dorson held special praise for fellow Harvard undergraduate Daniel Boorstin (1914-2004) as an Americanist. Dorson pointed to Boorstin's trilogy of American experience titled The Americans as "American Studies history" or "cultural history" at the grassroots that mainstream historians generally appeared to dismiss or ignore (Dorson 1979, 371). Boorstin, in fact, had been elected president of the American Studies Association (ASA) in 1969, and used its pulpit, according to his biographer John Diggins, to urge historians particularly to shed their awe of high-brow Europe and devote themselves to the prosaic, commonplace in America as a basis of American Studies (Diggins 1971). Boorstin also warned against the ASA taking an ideological position. He wanted American Studies to have an image of respected researchers rather than partisan activists. That did not mean he wanted to avoid confrontation and conflict. He advocated for keeping the lines of communication open among different sides in the Vietnam War debate and wanted Americanists to cover America, and Americans, as they spanned the globe. He foresaw a special public role for Americanists to provide background for contemporary issues with integrative studies of the United States during the Bicentennial of American Independence in 1976, and Dorson also considered this event a pinnacle moment for American Studies both in the United States and in Europe (Winks 1976).

12 Toward that end of emphasizing the vernacular in American Studies and suggesting an Americanist recasting of American experience, Boorstin had created the Chicago History of American Civilization series. Boorstin contracted Dorson to produce a book on American folklore in the series (Dorson 1959; see also Bauman, Abrahams, and Kalčik 1976; Bronner 1993; Mechling 1989). Critical to Boorstin's philosophy was the idea that unlike the European divide between high aristocratic and low vernacular culture, the United States was marked by "a homogeneity of thought and culture quite alien to the European experience" (Boorstin 1956, 140). With the United States having skipped the aristocratic phase, Boorstin claimed, the country was marked by its commonness. At the same time, American thought was diffuse, again in contrast to European intellectual life, Boorstin argued. He pointed out that the country lacked an intellectual center and philosopher class. American Studies could respond to this development by covering thought and culture in a conceptual whole. It could, and should, be "neither the history of our intellectuals nor the story of our philosophies," Boorstin declared $(1956,143)$. The Americanist in his view would be interested in the process rather than the product of America. Further, this type of scholar, whether from inside or outside the United States, should be the contextualist par excellence, able to 
identify broad cultural continuities and localized situations (see Berkhofer 1989). "By rejecting ideologies," Boorstin elaborated, "we reject the sharp angles, the sudden turns, the steep up-and-down grades, which mark political life in many parts of the world, in favor of the slow curves, the imperceptible slopes of institutional life" (1956, 150). American culture had taught its scholars to think institutionally, Boorstin opined, and this trait could effectively frame the direction for Americanists that incorporates, and yet separates itself from, the disciplines of history, philosophy, and literature (Boorstin 1956, 150; see also Berkhofer 1979; Bronner 2017; Murphey 1999).

Dorson picked up Boorstin's institutional cue in Wise's volume on the history of the American Studies movement. Dorson offered an ethnographic portrait of the differences among scholars of different disciplinary stripes from his experience at conferences. He characterized the American Studies type "having a certain flair that denotes a liberated spirit" that separates him or her from anthropologists ("rough and ready, gruff and hearty" he wrote of them), literature scholars (who, he wrote, "move discreetly and discourse courteously"), and historians ("matter-of-fact and pragmatic" he quipped) (Dorson 1979, 369). Although somewhat tongue-in-cheek, Dorson's characterizations were meant to verify a label of Americanist as independent from, rather than a supplement to, other disciplines.

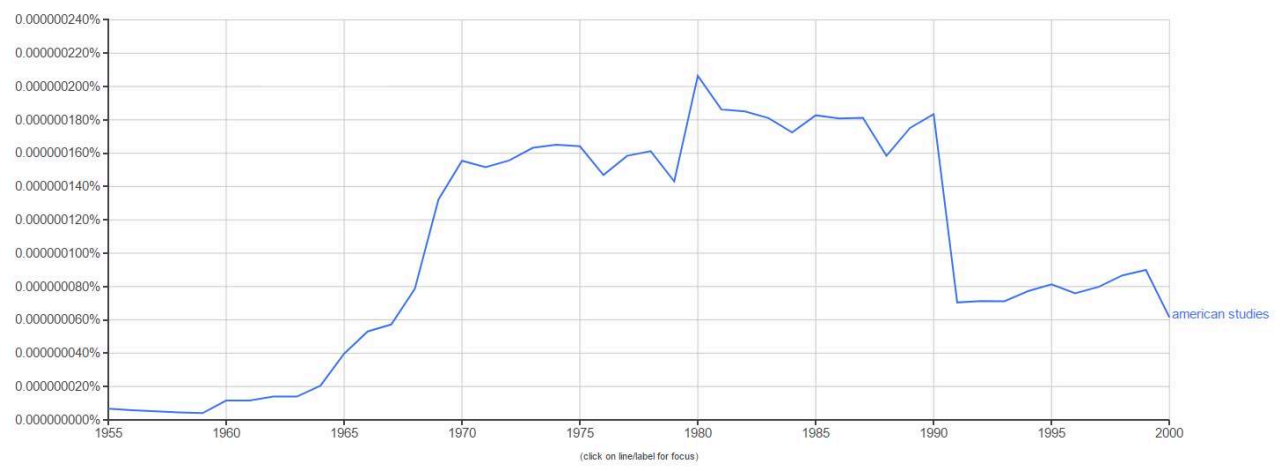

Fig. 1: Ngrams for American Studies, 1955-2000 (smoothing factor of 5)

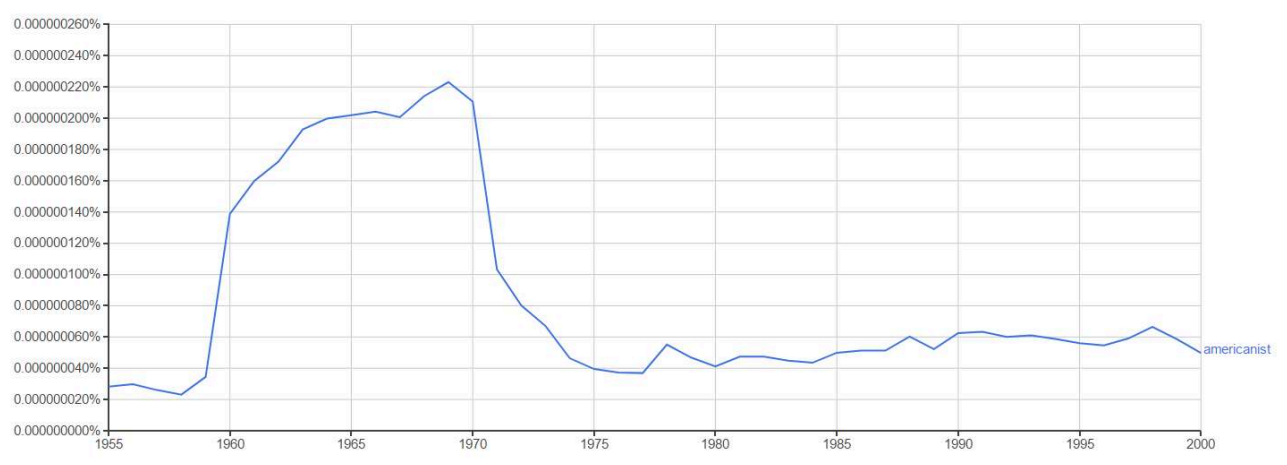

Fig. 2: Ngrams for Americanist, 1955-2000 (smoothing factor of 5)

One statistical indication of rhetorical usage of "Americanist" as a signal label for an American Studies scholar analyzing American culture at the grassroots rather than an American historian or literary scholar is through analysis of the Google books database. According to Ngram Viewer of Google Books, the title of "Americanist" rose dramatically 350 percent from 1960 to 1970 and then plummeted in 1980 back to pre -1960-levels (fig. 1). Yet use of "American Studies" continued at 1970 levels until dipping dramatically in 1990 (fig. 2). During the 1990s, six of the 10 presidents of the 
American Studies Association (ASA) either did not have American Studies degrees or were not affiliated with American Studies programs. The ASA awards program did not have any prizes named after the founding Harvard figures or the doctoral children that Dorson named, but featured accolades named after figures with affiliations outside of American Studies programs such as Angela Y. Davis, Lora Romero, and Yasuo Sakakibara.

Noting the expansion of attendance at ASA meetings beyond the core audience of representatives from American Studies programs and departments, reports from the ASA's committee on academic programs during the 1990s complained that the ASA was not doing enough for American Studies academic programs and the core Americanist base (Davidson 1993; Hilbish 1993). According to the Individual Member Survey of 1990-91, half of the ASA membership had joined less than 6 years before. American Studies or American Civilization degrees accounted for only 35 percent of the membership (Hilbish 1993, 4). In 1993, the ASA's Standing Committee on American Studies Programs organized a pre-convention meeting devoted to American Studies Program directors. The second session on "The Question of Identity" asked "What do we make of the decline of American Studies programs at the same time that membership in the American Studies Association reaches an all time high?" ("PreConvention" 1993). Reflecting later on the conflict during the 1990s between the old Americanist core and the emigres from other disciplines to the ASA, Matthias Oppermann in American Studies in Dialogue (2011; based on his dissertation for Humboldt University, Germany) argued that much of the conflict was over the main innovative project of American Studies to create a new cultural pedagogy which was dissipating with more attention to separate historical, literary, or art historical approaches brought by a tide of new members.

In response, Daniel Aaron, one of Dorson's American Civilization classmates at Harvard, in 2007 titled his autobiography The Americanist and maintained the need for what he dubbed a Whitmanesque conception of the American Studies scholar as a "practitioner of things American" (Aaron 2007, 1). He implied that American Studies as it had developed after the 1990s was more diffuse, more politicized, and less effective as a scholarly enterprise of Americanists. Again looking at Ngram statistics for contents of books in the period after the 1990s, Aaron was joined in the use of Americanist by a rising tide of scholars after a fallow period (fig. 3). Whether this rhetoric constituted a neo-Americanist movement (with impetus from a rising tide of European scholars) as a counter to insurgent atomizing trends of American Studies or is a signal of another schism is a question I address in the next section.

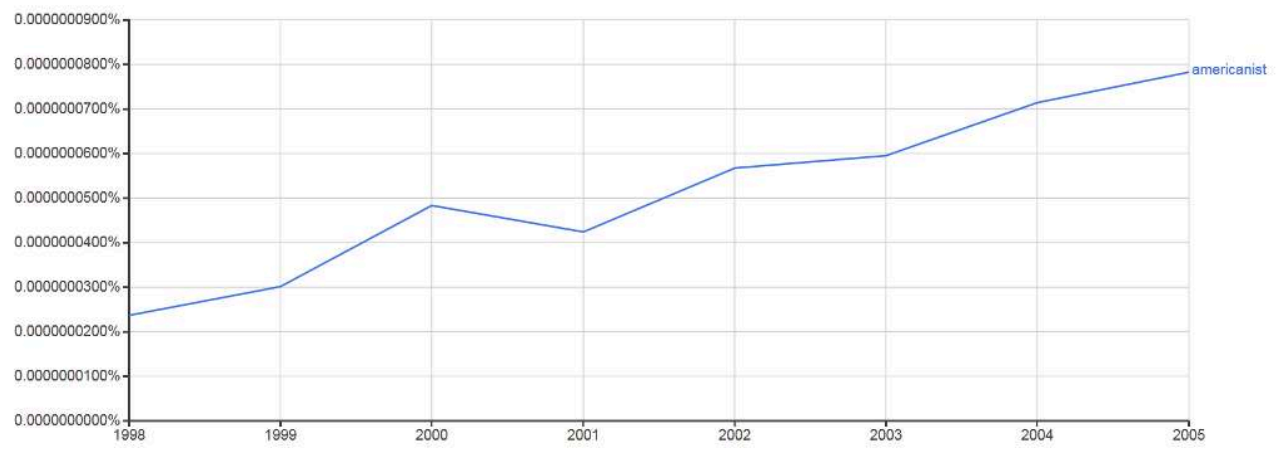

Fig. 3: Ngram for Americanist, 1998 to 2005, smoothing factor of 3 


\section{Contesting Claims for American Studies}

One sign of schism is the debates set off in 2003 by Leo Marx's identification of a "Great Divide" in American Studies (Marx 2003; Marx 2005; capitalization as in original). Marx, another of Harvard's original Americanist brood, observed that this divide was between the founding Americanist vision of a holistic, affirmative, nationalistic project "primarily aimed at identifying and documenting the distinctive features of the culture and society" and a new politicized regime that "undertook the serious empirical investigation of the often microscale oppositional identity politics generated by the barriers of gender, race, ethnicity, class, and sexual preferences" (Marx 2003-2004). The debate heated up to the point that Amy Kaplan, president of the American Studies Association in 2003-2004, issued "A Call for a Truce" (2005). She hoped there would be common ground in paying "more attention to the nation-state in American studies, [because]... in focusing so much on national identity from a cultural perspective, we haven't spent enough time on state, governmental, and economic institutions or the relations between state and nation" (Kaplan 2005, 143). Yet she rejected his holistic vision of seeing "America as a whole" and accused him of sticking to "exceptionalism" that she found repulsive. ${ }^{2}$ She preferred work since the 1990s of the "idea of America as an ideological, discursive, or mythic construct, an 'imagined community' that excludes as well as includes, that has hierarchical and imperial as well as egalitarian and democratic dimensions" (Kaplan 2005, 143; see also Gillman 2005; Kaplan and Pease 1993). Yet critics viewed this idea of America as another form of exceptionalism that substituted an aggregated malevolent image for "America's promise" (Radway 2009; Roark, et al. 2017).

Both Marx and Kaplan wanted to take credit for their versions of American Studies globalizing work on American culture; considering American ethnic, gender, and racial diversity; and expanding, as well as complicating, the meaning of America. Kaplan thought the embrace of these areas owed to a younger post-Cold War generation, while Marx claimed that these trends were original contributions of his founding American Studies cohort. Kaplan concluded that maybe a truce, or coalescence, was not possible as had occurred during the 1970s. She confessed that "after calling for a truce, I did nonetheless get into a defensive attack mode" (Kaplan 2005, 146). And others launched salvos on a mode of thinking they pejoratively called nationalist and simplistic in a binary with supposedly global and complex frame of study that was preferred for an era variously dubbed "postmodern," "post-nationalist," or "postcolonial" (Rowe 2000; Rowe 2002a; Rowe 2002b).

19 For American Studies academic administrators participating in a forum on "The New Goals of American Studies Programs" in 2005, the divisive issue was not the focus on diverse or global identities, which they agreed had been apparent in American Studies since its founding, but the matter of changing scholarly practice and organizational development (Bronner 2005; see also Bronner 2008). Their worry was that papers at American Studies Association meetings and publications in its journal American Quarterly disclaimed objective, rigorous methodology or research in favor of political grandstanding. Indeed, the ethnic inclusiveness of earlier meetings appeared to them undermined by factions that wanted to ostracize ethnic and religious groups they characterized as favoring a nationalistic or superordinate position (see Castronovo and 
Gillman 2009; Wood 2013). Particularly pointed in this view was Walter W. Hölbling of the Department of American Studies at the Karl-Franzens-University in Austria. He observed from a European perspective an unnecessary implosion of American Studies as practiced by scholars in the United States. He wrote, "Looking at the U.S. from... across the ocean, the object of our study-the United States-is still clearly discernible and has not disappeared" (Hölbling 2005, 15). He emphasized the keywords of inclusiveness and everyday (and an added call for attention to popular culture and media) as intellectual concerns in the conclusion of his essay: "For our teaching of U.S. culture and society, only an inclusive approach guarantees the necessary, and certainly the more authentic, complexity and differentiation in our understanding of the U.S. to make students aware that the flood of simulacra they receive via everyday mass media are mostly rather stereotyped versions of 'American' reality" (Hölbling 2005, 17). Takashi Sasaki of the Graduate School of American Studies of Doshisha University in Japan agreed and thought that the inclusive approach of Americanists should include the objective perspective of social sciences "necessary," he wrote, "for Americanists outside the United States to position American Studies in a global context" (Sasaki 2005, 14).

20 The debate at the dawn of the new millennium was the not first time that American Studies divided over the charge of politicization and analytical subjectivity. In his ASA presidential address in 1990 titled "The Politics of American Studies," Allen Davis recalled turmoil within American Studies during the 1970s as a result of the agitation of the "Radical Caucus" in the American Studies Association (ASA) and protests at international American Studies conferences of America's presence in Southeast Asia and Europe. He opened with the example of the disruption of speakers at a global conference at Salzburg, Austria, sponsored by the Bicentennial Committee for International Conferences of Americanists, United States Information Agency, and the Bureau of Educational Cultural Affairs of the United States State Department. These unprecedented events, according to Davis, owed to "a considerable debate about the relationship between American Studies scholarship and American money and power" $(1990,354)$.

21 Although the rise of American Studies could be tied in Europe and North America to what Davis called "the cold war climate" of democratic opposition to the Soviet Union by supporting American Studies programs, discontent had grown among American Studies scholars with America's involvement in Vietnam. Some scholars such as John William Ward held the view that scholarship should more vociferously combat America's militarism (Brown 2006), while others maintained that scholarship should keep a social scientific objectivity (Cole 1971; see also Dorson 1976b, 21-24). Davis reflected that the label of radicals the group gave itself was not apt because they were not really revolutionaries or extremists. In his view, "they merely wanted to transfer some of the movement for freedom and equality they witnessed all round them to their teaching and learning" and invoked radicalism to draw attention to their resistance generally, in the rhetoric of the period, to a societal "establishment" (Davis 1990, 360; see also Deloria and Olson 2017, 100-4). Especially after riots in 1968 during the Democratic National Convention and the assassination of Dr. Martin Luther King Jr., they sought new dialogues on the purposes of American Studies scholarship to be relevant to American social realities. And they were not alone - even more dissident 
movements arose within the American Historical Association and Modern Language Association (Davis 1990, 360).

A contentious moment or "representative act" for the American Studies movement began in 1969 at the American Studies Association conference in Toledo, Ohio, when the group identifying as "The Radical Caucus" threatened to divide the ASA over student representation on the ASA Council, involvement of Third World countries in the American Studies movement, continuation of the Civil Rights movement, and opposition to the Vietnam War. The matter appeared to have been resolved by 1971 with negotiations to change ASA policies and election procedures. In his report to the ASA, president Robert Walker declared that "a wasteful and destructive confrontation was avoided" (Walker 1971, 260). Walker commented that accord was reached because both sides agreed on maintaining the professionalism, rather than political partisanship, of scholars in the American Studies movement. According to Walker, "It should be clear by now that, in spite of the terminology [of 'radical'], the ASA has not been 'politicized"' (1971, 260). Referring to surveys conducted by the ASA Council, Walker claimed that "the very large majority of the membership has expressed a strong wish that the ASA remain a professional association and avoid stands on political issues external to immediate professional concerns" (1971, 260; emphasis added). Davis reflecting on the turmoil two decades later agreed with Walker's assessment that "the sympathetic hearing extended to the Radical Caucus prevented the division that occurred in other professional organizations" $(1990,362)$. He also observed another consequence of the conflict: the ASA became more of a national body rather than a federation of regional organizations. This nationalization appeared in keeping with a push to establish American Studies as a discipline with a global group that met annually in prominent locations and represented a primary affiliation for its members.

\section{The Challenge of Culture in American Studies}

One schism that could not be resolved, however, was with a faction of Americanists who propounded the transformation of the diffuse-sounding label of "American Studies" into a more focused American cultural studies. This designation, its advocates maintained, would be more populist and democratic by giving more attention to folk and popular culture. This group, led by some of the original founders of the ASA including Russel Nye, Ray Browne, and Marshall Fishwick, claimed that the ASA was elitist in its historical and literary subject matter and in the kinds of scholars who participated in its conferences. In response, the trio launched a Midwest Conference on Literature, History, Popular Culture, and Folklore at Purdue University in 1965 that was meant to draw attention to material, and approaches, allegedly left out of the purview of "American Studies." The regional conference was in keeping with the organizational landscape of American Studies which was lodged in regional organizations (Davis 1990, 357). The challenge of the papers to elitist American Studies scholarship led Ray Browne working with Donald M. Winkelman and Allen Hayman to issue the conference proceedings as New Voices in American Studies in 1966 and launch the Journal of Popular Culture (JPC) in 1967 (Browne, Winkelman, and Hayman 1966). The inclusive rhetoric of "voices" was Whitmanesque in invoking the poet's populist reference to "different voices winding in and out" in Leaves of Grass (1900, 343; see also Gray 2015, 69-105) and drawing attention in the midst of the civil rights movement to suppressed ethnic and 
racial differences in the more recent title of 12 Million Black Voices: A Folk History of the Negro in the United States by Richard Wright (1941). Browne still expressed the hope that his vernacular culture initiative could transform rather than displace the American Studies movement. Writing in the introduction under the heading of "The Proper Study for American Studies," Browne observed "the various fields loosely associated with 'American Studies' have developed into a coherent discipline with momentum" (1989, 10), but bemoaned the elitism of American Studies reflected in the lack of attention to folk and popular culture. With this attention, Browne hypothesized, American Studies could fill an intellectual niche not covered by history, English, and social science.

Nye organized the ASA meeting in 1969 in Toledo with the hope of featuring popular culture studies and more broadly to encourage a shift of American Studies toward an American cultural studies. Impatient with the rate of change within the ASA, however, Russel Nye and Marshall Fishwick after the meeting in 1969 called for an organization that was independent of the ASA (Browne 1989, 21). Browne recalled that they "still felt that the focus of the ASA was too narrow, too elitist and not sufficiently relevant" and was not transformable (Browne 1989, 57). After consideration of intellectual terms for their group including "contemporary culture" and "comparative culture," and in light of folklorists already having an American Folklore Society, they decided on the global label of "popular culture" within a Popular Culture Association. Despite Browne's hope that it was meant to supplement the ASA's activities, he realized that the ASA "continued to look upon us as a deliberate threat" (Browne 1989, 22). The Popular Culture Association grew rapidly and gained a populist reputation as an organization that did not limit participation to academics. Whereas previously he had avoided establishing an organizational competitor to the ASA, in 1978, Browne launched a Journal of American Culture (JAC) as the organ of a new American Culture Association (Browne 1978, 57). The emphasis in the name was the substitution of "culture" for the diffuse "studies." The American organization met with the Popular Culture Association (PCA), but was not limited to popular culture. As he explained the difference, "A paper on the influence of Puritanism in the printing trade would belong to JAC, but one on the effect of Puritan hymnals on Protestant songs would properly belong in JPC" (Browne 1989, 58). Nonetheless, the difference to many scholars was not entirely clear and the label of "American culture studies" was often associated with popular culture studies. Indeed, the ACA appeared to be more concerned with developing theories related to popular culture and media studies than to developing American Studies as a discipline.

Undoubtedly, popular culture studies drew people away from American Studies which still had by the 1990s an elitist academic reputation, but increasingly, a number of programs took on the "American culture" label and by the start of the new century ASA conferences featured more popular culture in their purview (Berkhofer 1989; Mechling, Merideth, and Wilson 1973; Shank 1997; Sykes 1963). Yet a difference in approach could be discerned. Textbooks by PCA/ACA leaders touted an "iconology" in popular culture studies that would have as its goal the identification and interpretation of popular American icons, including celebrities, products (especially film and music), and institutions (Berger 2012; Browne, Grogg, and Landrum 1975; Cottrell 2015, Fishwick and Browne 1970; Hinds, Motz, and Nelson 2006; Lewis 1972; Nye 1970). In turn, ASA conferences worked to champion more of the ethnic and racial diversity that the PCA/ ACA had claimed was missing from the ASA. 
26 ethnographic methods to supplement historical and literary approaches to ethnic, ordinary, or vernacular lives, but also in the emphasis on the diversity (often ethnic, occupational, regional, and gender) of plural cultures and migratory nature of traditions across borders (Bauman, Abrahams, and Susan Kalčik 1976; Bronner 1993). Through folklore, Dorson asserted in a volume co-edited by Ray Browne, one is able "to see American culture from new angles" (Dorson 1971, 79). The perspective is from the bottom up with special attention to social life and the agency of communities in the use of traditions. Instead of viewing a hierarchy on a ladder of civilization from the lowly folk to the elite at the top, he sketched a relationship of folk as the root of popular, mass, and elite ideas (Dorson 1971, 91). He declared that the influence of folk cultural research is one that forces students out of the library and into the field and that has them thinking comparatively about American social "reality." He identified an obstacle in American Studies in the "professional resistance to local as opposed to national history" (1971, 87); if that could be overcome, he editorialized, then a new generation of students will be able to give "sound, perceptive treatments" of a plural American culture $(1971,93)$. With the obstacle of national history removed, Dorson's bridging of the ethnographic present and historic past as well as the keynote of plural culture are evident in the definition of American Studies given in American Studies: A User's Guide by Philip J. Deloria and Alexander I. Olson for the twenty-first century: "American Studies is an interdisciplinary practice that aims to understand the multiplicity of the social and cultural lives of people in-and in relation to-the United States, both past and present (2017, 6; emphasis added).

The understanding brought to these lives in American Studies often appeared to be critical. Surveying books on American culture produced by ASA leaders, Alan Wolfe (2003) characterized many of the books from new students with American Studies affiliations as "anti-American Studies" because as a group they took a negative view of the United States with harsh complaints about lingering inequality, marginalization, and injustice in American Society. They frequently referred to the inspiration of Antonio Gramsci and the Birmingham School of "cultural studies" that unlike Boorstin argued for a class-based conception of American society beset by conflicts between an elite who used popular culture to manipulate the masses and an underclass that suffered from its racialization and feminization (Lears 1985; Storey 2009; Wolfe 2003). As Günter Lenz in his chronicle of the "New American Studies" points out, European neo-Marxist thought was attractive because of "its critique of the self, of history, of enlightenment, not only in terms of an inherent critique of philosophy, but as historical and social process" $(2017,11)$. Yet what Lenz called the Left's "deconstruction of all the traditional foundations and strategies of critical discourse" led to a "trap of a superficial synthesis or a harmonization of oppositions, contradictions, or difference" $(2017,3)$. Although critical theory picked up on issues of plurality, globalism, and inequality anticipated by the founders of the American Studies movement, Lenz thought that the crisis of the Left in the post-civil-rights era of the 1980s when liberalism became mainstreamed in academe led to a rejection, or deconstruction, of progressive theories so as to establish a radical presence of political interventionism (2017, 5, 62-88). It suggested in Gramscian terms that a problem with America was its intellectual construction by Americanists. Despite their calls for building an inclusive inquiry into American experience, warts and all, the Americanists intellectually constructed as "old" and even reactionary, were scapegoated as being complicit in 
modern American social problems. In other words, the new American Studies ironically undermined the need for American Studies.

For many scholars invested in this revisionary "new American Studies," the American Studies movement born at Harvard and Yale did not constitute a foundation on which to build a changing edifice; scholars looking for a synthesis needed to look elsewhere, perhaps in European neo-Marxist thought, or start anew (see Oppermann 2017). In this view, American Studies should be dissolved and replaced with a new paradigm of an atomized, problematized, and illusory America in the world (see Kaplan and Pease 1994; Lipsitz 2001; Pease and Wiegman 2002; Rowe 2000; Rowe 2002b). There did not appear to be much room for negotiation as there had been with other paradigm dramas. Again, the issue of naming came up to give separation from the Americanist movement. In a signal of the crisis of American Studies as constituted in the American Studies Association, Janice Radway in her presidential address to the ASA notably challenged the naming of American Studies and called for a label to convey "the importance of difference and division within American history, on the significance of 'dissensus'..." (Radway 1999, 2). This new label would guide the American Studies Association, she thought, in redefining its role "in a larger social and political context" and potentially changing its identity as well as its name $(1999,2)$. To do so, she simplified, and demonized, the Americanist position as promoting American culture to be "exceptional in some way and...dominated by consensus" $(1999,2)$, even though Dorson's characterization of the founders was that they indeed were innovative by exploring social difference, global connections, and indeed issues of empire (see DeVoto 1952; Jones 1964). Radway thought that American Studies enforced "the achievement of premature closure through an implicit, tacit search for the distinctively American "common ground"' $(1999,3)$. She wanted to separate American Studies from what she called "a rapidly advancing global neo-colonialism that specifically benefits the United States, by an association whose very name still so powerfully evokes the ghostly presence of a phantasmatic, intensely longed-for, unitary “American' culture” $(1999,8)$.

Radway considered three possibilities for conceptual as well as onomastic change. One was to rename the ASA the Association for the Study of the United States, so as to refocus attention away from the "American" label which she thought of as an "imperial gesture" $(1999,18)$. She worried, however, that this alternative would alienate international scholarly communities. She wrote that perhaps adding "International" to the association would be more inclusive, but then again, it was not in keeping with the radical stance that situating a study by political borders leads to a "greater isolationism in the intellectual construction of the U.S." $(1999,20)$. She then considered the "InterAmerican Studies Association" to focus on transnational American social and cultural relations. Then again, she backtracked, "such a name would implicitly place the entire 'American' field in relation to the imperial Europe that first began to define it" (1999, 20). In her globalizing onomastics, she strived to create distance from colonizing Europe as well as the United States. Her culminating suggestion was a "Society for Intercultural Studies" to eliminate the space of America as an organizing rubric for an "area study." To its credit, "intercultural" would signal a post-structural turn away from the nationalism, she thought, but was concerned that in an era of global massification that "it would be particularly dangerous to do away with the respect for local contexts" $(1999,23)$. The American Studies Association did not change its name as a result of her address, but it did arguably become radically recast. Or maybe it was not so radical as the New Americanists thought. Matthias Oppermann writing on the 
history of American Studies noted that they adhered to the old elitist "paradigm of print texts" and he was surprised that they still gave little attention to media, visual culture, and popular culture, as the Americanists had $(2017,19)$.

Despite Radway's expressed concern for expanding the internationalization of American Studies at century's end, a number of scholars thought the effort did not go far enough in recentering holistic scholarship on the United States. On June 1, 2000, twenty-two professors meeting in Bellagio, Italy, launched the International American Studies Association with the purpose of providing, according to its website, "a space for interdisciplinary dialogues about American culture and society." It declared itself to be the "only world-wide, independent, not governmental association for Americanists" (Jaidka 2017). It challenged the ability of the American Studies Association with its foundational context in the United States of being able to "speak with authority and understanding about U.S. culture" (Jaidka 2017). It also referred to a critical mandate, but one more focused on "critical internationalism" that countered the perceived "insularity" of ideas by United States scholars assumed to have universal validity (Desmond and Dominguez 1996; Lee 1995). Seeking reconciliation as president of the ASA, Emory Elliott brought up the IASA's concerns in his presidential address to the ASA and hoped that resolution could be achieved by having more dialogue as an extension of the pedagogical concept of diversity between "those of us who study the United States from the inside and those who do so from the outside" (Elliott 2007, 6). Validating the organizing principle of the IASA, he urged ASA members to "carefully consider outside perspectives and criticism," but also thought that the ASA is "uniquely positioned to explore the transnational without undermining the political and institutional stakes of these other fields and programs" (Elliott 2007, 9-10). The IASA remained independent, however, and produced its own publications and conferences outside the United States.

31 Even if embracing critical internationalism could be a connecting thread among the emerging factions of the Americanists and the new American Studies, the ASA's slide toward politicization of its subject caused unrest from within. With the provocative title of "The Idiocy of American Studies," Steven Watts in 1991 admonished the poststructuralist "hordes" in the new American Studies that "its injunctions have created an interpretive framework that is one-dimensional, while it has defined a politics that may be compelling for its academic practitioners, but is of little use otherwise" (Watts 1991, 627). Watts's warning in the ASA's organ of American Quarterly did not stop the tide of critical works, including several special-theme issues concentrating on conflict, such as Sound Clash: Listening to American Studies (2011), Race, Empire, and the Crisis of the Subprime (2012), and Species/Race/Sex (2013). Acknowledging in 2015 that the new American Studies with its anti-nationalist orientation had become aggressively dominant and intolerant of opposing views of scholars working in American culture, popular culture critic Michael Walsh in The Devil's Pleasure Palace caustically chided the upstarts for the "pernicious" effects of its "reactionary philosophy of "critical theory" (Walsh 2015,1$)$. He animatedly characterized this cultish scholarship as "overly intellectualized and emotionally juvenile" and responsible for a subversive function of "destruction, division, hatred, and calumny" in American society-all "disguised as a search for truth that will lead to human happiness here on earth" (Walsh 2015, 1).

32 As the range of editorial jabs between 1991 and 2015 shows, this latest battle in American Studies lasted longer than the earlier crises of the 1970s and appeared less 
resolvable. In the midst of this growing public debate, several American Studies programs that had played significant roles in the American Studies movement closed. A number of prominent long-standing programs such as Indiana University (Dorson's base), Michigan State University (home to Russel Nye), and the University of Pennsylvania (one of the first programs to be established) shut down. Other programs became embedded in departments hanging post-structural shingles: the American Studies program at the University at Buffalo came under the auspices of a department of transnational studies, Washington State University's program joined the department of critical culture, gender, and race studies, and New York University's program was administered by the department of social and cultural analysis.

That is not to say that the American Studies landscape had become monolithic. An ASA survey of programs in 2007 noted that many American Studies programs had dropped their claims of interdisciplinarity as their raison d'etre in favor of calls for cultural interpretation and applied work (Bronner 2008). The doctoral program in American Studies and Ethnicity at the University of Southern California was committed, according to its website, to "the consequences of disparity and inequity, and the enactment of community and citizenship in Los Angeles, California, the United States and the world." The doctoral program in American Studies at Penn State Harrisburg, established in 2009, meanwhile declared its allegiance to the American Studies movement's "understanding of the American experience developed within the intellectual legacy of American Studies." Despite the addition of these two doctoral programs, ASA leaders became concerned about a perceived decline in American Studies programs overall and a downturn in ASA membership since 1993. In response, the ASA Council in 2014 established a task force "for American Studies in Higher Education in the U.S. and Globally" (Task Forces 2014). Apparently concerned for public skepticism of American Studies as a viable intellectual field, the task force announced its primary objective of making "a case for the centrality of American studies within and across contemporary discourses of higher education, civil society, and democracy so as to ensure a vibrant future for the field" (Task Forces 2014).

A twofold change occurred during years of American Studies program crisis in the early twenty-first century. One was the "topic drift" away from American Studies as a new perspective on American culture and another was the appropriation of scholarship in service to ideology rather than intellectual discovery. Charles Kupfer in 2016 protested that the new American Studies "now serves chiefly as validation system for academicians who know their findings in advance: racism, sexism, and imperialism." He was not objecting to interrogations of racism, sexism, and imperialism in American experience, but rather the fallacious methodology of presenting a priori assumptions as conclusions. Activism, he worried, was presented as theory. Looking for an analytical methodology whose findings were confirmable and would garner academic respect, he complained that in the critical paradigm claimed by the new American Studies, "studies" meant a dubious conclusion of "call-outs and condemnations." Yet what he referred to as the field might represent the proclamations of the American Studies Association rather than an active group of Americanists, especially those attracted to the holistic concept from abroad. 


\section{The Causes of Civil War and Its Aftermath}

Divisions within American Studies came to a head in 2013 when the ASA's National Council proposed a resolution to endorse a boycott of Israeli institutions (Mullen 2015; Musher 2015). Although the action was on a single resolution, the result was a civil war on a host of issues related to the future of American Studies. Despite opposition of eight former presidents of the ASA to the proposal, the ASA Council moved ahead with the resolution. The result was the withdrawal of several American Studies programs from the ASA's institutional membership, a host of high profile criticisms of the ASA by American Studies scholars, and widespread public opprobrium for the ASA (Kulik 2013; Organizations 2017). Indeed, a journalist for the Chronicle of Higher Education (January 5, 2014) characterized the American Studies Association as "a pariah of the United States higher-education establishment" (Schmidt 2014). The term "American Studies" was tainted by links to the ASA, particularly after over 200 university presidents in the United States condemned the ASA's resolution and its academic leaders (Schmidt 2014).

With the field inviting closer public scrutiny because of the resolution, commentators noted that American Studies no longer represented intellectual innovation and appeared fragmented into innumerable areas: ethnic studies, Native American Studies, gender studies, cultural studies, and so on (Kupfer 2016; Pells 2016). The "studies" became a problem in an intellectual landscape that no longer considered interdisciplinarity special as an academic distinction (Klein 1999). Through the twentieth century, American Studies programs touted the initiative of American Studies in advancing interdisciplinary models in academe, but with the proliferation of integrative curricula, American Studies in the twenty-first century did not stand out as a bellwether (see Moran 2002). After praising American Studies as the most innovative movement in the American and international academic world from the 1940s to the 1960s, intellectual and cultural historian Richard Pells from the University of Texas in 2016 critiqued the new American Studies as purposeless, irrelevant to the outside world, and narrow in its subject matter.

Still, the question remained whether the tarnished image of American Studies resulted from the actions of the ASA which represented the field or the turf wars among departments within American universities (see Augsburg and Henry 2009). For example, appearing on the nationally broadcast Charlie Rose Show (PBS) former president of Harvard University Larry Summers suggested that the ASA did not meet the standards of a learned society and encouraged university presidents not to subsidize participation in or travel to ASA meetings (ASA Members for Academic Freedom 2013). Drew Gilpin Faust, Summer's successor at Harvard, who had been part of the University of Pennsylvania's American Studies program as student and faculty member, announced on behalf of Harvard University disapproval of the ASA's boycott (Office of the President 2013). Faust was joined in condemnation of the ASA by most institutions with American Studies programs and members of the ASA National Council, including Yale University, Brown University, and New York University (Jacobson 2013). of concern to many Americanists was that the actions of the American Studies Association were dragging down the reputation of American Studies as a legitimate field of learning (Kulik 2013).

Empirical evidence of the troubles of American Studies well before the boycott resolution was provided by Jerry A. Jacobs in 2013 of the Population Studies Center at 
the University of Pennsylvania. He pointed out that "Even at its peak of popularity in the early 1970s, a mere two-tenths of one percent of undergraduates [and less than one-twentieth of one percent of master's students] obtained their degrees in American Studies, and only a slightly higher fraction of doctorates were granted in this field" (Jacobs 2013, 1). He added that in his count, "most of the presidents of the American Studies association over the last 20 years had their principal appointments in either English or History departments" (Jacobs 2013, 1-2). He drew significance from the fact that many scholarly endeavors undertaken by those with training in American Studies are just as narrow and specialized as those pursued by their counterparts trained in English and history. Jacobs concluded that as a result of the fragmentation of topics, "American Studies programs have declined in number and have not recouped these losses" (Jacobs 2013, 16). The highest attrition rate was in master's degree programs in small colleges.

The window of opportunity, however, is that the survival rate of doctoral programs in American Studies was relatively strong at 75 percent, and with their continuity, could be the basis of a revitalized movement away from the ill-starred direction fermented by the American Studies Association. Jacobs's diagnosis was that "For the emerging paradigm to endure, it must continue to generate a dynamic research agenda that elicits commitment from succeeding generations of scholars" (Jacobs 2013, 35). I propose that a need still exists for a holistic project to document and interpret American culture in a diverse local, regional, and global context much as Dorson envisioned. To be sure, the project has evolved and the addition of more social sciences, awareness of digital culture and media, practice and performance theory, studies of bodylore and embodiment, and new perspectives on gender, tradition, and aging have informed a new paradigm built upon the foundation of an Americanist intellectual legacy. But when the dust settles, the Americanist label for the professional investigator and for an alternative professional organization is crucial if the project is to have a future.

\section{Rebirth: In Consideration of Americanistics}

In conclusion, I will answer Jacobs's call with a trifold proposal of a dynamic research agenda that I hope can be sustained in a revitalized movement of Americanists.

1. Differentiate "American Studies" in addition to English and History from an Americanist agenda of an integrative project primarily aimed at identifying, documenting, and analyzing the characteristic features of the diversity and unity of American culture locally, nationally, and globally. As Skard noted, attention needs to include not only the influence of the world upon and within America, but also on America in the world. This differentiation might be accomplished by American Studies programs with Americanist goals designating their distinctive scope with the label of "American Thought and Culture" or as I will outline below a field of learning called "Americanistics." Programs could also add "Society" to emphasize sociological as well as cultural aspects. Indeed, this subject should integrate social sciences as well as humanities by appealing to anthropological and sociological Americanists who have a parallel tradition. Organizationally, the students of the subject can align with centers and groups that promote open dialogue such as the John F. Kennedy Institute for North 
American Studies, European Association for American Studies, and the Society of Americanists rather than the American Studies Association. ${ }^{3}$

2. The designation of a field or a discipline by its content is problematic. It has plagued the study of folklore and popular culture, for example, although folklore has a label for a professional "folklorist" which popular culture does not have. One possibility is to align with social sciences with a suffix of "ology" such as "Americanology" but more closely related to Americanist is a variation of linguistics such as Americanistics. In German-speaking countries, Americanistik is already in usage with connotations of cultural historical and social scientific concerns (Strunz 1999). ${ }^{4}$ Anticipating this rhetorical move in English, Rob Kroes pointed to the establishment of a chair in Americanistics in the Netherlands in 1947 as instructive. He considered "American Studies-as an American approach brought over to Europe...an anachronism" (1987, 56). Understanding "the rival concept" of Americanistics as moving beyond its origins in language study to society and culture, the difference from American Studies, he argued, is its "consistently stereoscopic vision," an analytical comparative perspective that takes into account perceptions from within the United States as well as outside of it (1987, 56, 62-63). The appeal of "ics" as a suffix is its connection not only to systematic identification but also to the interpretation of meaning (see, for example, the discourse on the designation of folkloristics as the study of folklore in Ben-Amos 1985; Bronner 2006; Montenyohl 1996). It also suggests an adjective of an Americanistic project to describe studies taking a holistic approach. Ultimately, the designation is important to differentiate from the Americanist as a professional endeavor from the lurkers and grandstanders of American Studies.

3. Ultimately, the Americanist agenda is dynamic and inclusive because it offers as ethical guidelines of professionalism an objective search for social and cultural patterns and an a diverse community of practice, if not a discipline, devoted to goals of cumulative scholarship. It can evolve in the movement as an intellectual enterprise to identify and explain patterns, ideas, and traditions characterizing the nation and its people in regional and global contexts. As a discipline it is based on an intellectual heritage reaching into the late nineteenth century (Bronner 2017).

Most of all, Americanistics is a problem-oriented approach, spirit, or "way of seeing things whole" (Bronner 2017; Küchler 2017, 25-28). It can be an independent branch of learning although it clearly draws upon ethnographic, psychological, and historical perspectives on everyday life and vernacular culture. Organizationally, it should restore the inclusive "stream of ideas" from different sectors that could lead to coalescence. This proposal for a "re-birth" of the Americanist agenda will undoubtedly look different from the American civilization concept Dorson knew at Harvard, but I hope it will produce the "exhilaration" he and his fellow liberated spirits felt at pursuing, and affecting, the expanded, changing meanings of America in the world.

This essay is a revised version of a paper delivered at Society of Americanists meeting, March 31-April 1, 2017, Harrisburg, Pennsylvania. I wish to acknowledge the lively discussion from the audience that informed my revision, and the separate comments of Charles Kupfer, Anthony Buccitelli, and Spero Lappas. 


\section{BIBLIOGRAPHY}

Aaron, Daniel. 2009. The Americanist. Ann Arbor: University of Michigan Press.

Abrahams, Roger D. 1989. “Representative Man: Richard Dorson, Americanist.” Journal of Folklore Research 26: 27-34.

ASA Members for Academic Freedom. 2013. "Lawrence Summers Discusses Proposed ASA Boycott Resolution on Charlie Rose Show." YouTube https://www.youtube.com/watch?v=yW__sylpHJM. Accessed May 23, 2017.

Augsburg, Tanya, and Stuart Henry, eds. 2009. The Politics of Interdisciplinary Studies: Essays on Transformations in American Undergraduate Programs. Jefferson, NC: McFarland.

Bassett, Charles W. 1975. "Undergraduate and Graduate American Studies Programs in the United States: A Survey.” American Quarterly 27: 306-30.

Bauman, Richard, Roger D. Abrahams, and Susan Kalčik. 1976. “American Folklore and American Studies." American Quarterly 28:360-77.

Beauchamp, Gorman. 1984. "Big Brother in America." Social Theory and Practice 10: 247-60.

Ben-Amos, Dan. 1985. “On the Final [s] in “Folkloristics.”' Journal of American Folklore 98: 334-36.

Berger, Arthur Asa. 2012. Understanding American Icons: An Introduction to Semiotics. Walnut Creek, CA: Left Coast Press.

Berkhofer, Robert F., Jr. 1979. “The Americanness of American Studies.” American Quarterly 31: $340-45$.

.1989. “A New Context for a New American Studies?” American Quarterly

41: 588-613.

Boorstin, Daniel J. 1956. “The Place of Thought in American Life.” American Scholar 25: 137-50. . 1965a. The Americans: The National Experience. New York: Random House. . 1965b. The Americans: The Colonial Experience. New York: Random House. . 1965c. The Americans: The Democratic Experience. New York: Random House.

Bronner, Simon J. 1982. “In Tribute: Richard Dorson, 1916-1981.” Center for Southern Folklore Magazine 4 (2): 1.

. 1993. "Exploring American Traditions: A Survey of Folklore and Folklife Research in American Studies." American Studies International 31: 37-69.

. 1998. Following Tradition: Folklore in the Discourse of American Culture. Logan: Utah State University Press.

, ed. 2005. "Beyond Interdisicplinarity: The New Goals of American Studies Programs." American Studies Association Newsletter 28 (March): 1-17. . 2006. "Folk Logic: Interpretation and Explanation in Folkloristics." Western Folklore 65: 401-33.

. 2008. "The ASA Survey of Departments and Programs: Findings and Projections." American Studies Association Newsletter 31 (March): 11-19. 
. 2017. “American Studies: A Discipline.” In Encyclopedia of American Studies, ed. Simon J. Bronner. Baltimore: Johns Hopkins University Press. http://eas-ref.press.jhu.edu/view?aid=809. Brown, James Patrick. 2006. "The Disobedience of John William Ward: Myth, Symbol, and Political Praxis in the Vietnam War." American Studies 47: 5-22.

Browne, Ray B. 1989. Against Academia: The History of the Popular Culture Association/American Culture Association and the Popular Culture Movement, 1967-1988. Bowling Green, OH: Bowling Green State University Press. , Sam Grogg, Jr., and Larry Landrum, eds. 1975. Theories and Methodologies in Popular Culture. Bowling Green, OH: Bowling Green State University Popular Press. , Donald M. Winkelman, and Allen Hayman, eds. 1966. New Voices in American Studies. Lafayette, IN: Purdue University Press.

Castronovo, Russ, and Susan Kay Gillman, eds. 2009. States of Emergency: The Object of American Studies. Chapel Hill: University of North Carolina Press.

Cole, R. Taylor. 1971. “American Studies in Western Continental European Universities.” In Theory and Politics/Theorie und Politik, ed. Klaus von Beyme, 242-58. The Hague: Martinus Nijhoff. Cottrell, Robert C. 2015. Icons of Popular Culture: From P.T. Barnum to Jennifer Lopez. New York: Routledge.

Davidson, Cathy N. 1993. "Revision of Program Committee's Work and New Guide to American Studies Resources.” American Studies Association Newsletter 16 (September), 3.

Davis, Allen F. 1990. “The Politics of American Studies.” American Quarterly 42: 353-74.

Deloria, Philip J., and Alexander I. Olson. 2017. American Studies: A User's Guide. Berkeley: University of California Press.

Desmond, Jane, and Virginia Dominguez. 1996. "Resituating American Studies in a Critical Internationalism." American Quarterly 48: 475-90.

DeVoto, Bernard. 1952. The Course of Empire. Boston: Houghton Mifflin.

Diggins, John P. 1971. “The Perils of Naturalism: Some Reflections on Daniel J. Boorstin's Approach to American History." American Quarterly 23: 153-80.

Dorson, Richard M. 1959. American Folklore. Chicago: University of Chicago Press. . 1971. American Folklore and the Historian. Chicago: University of Chicago Press. . 1976a. The Birth of American Studies. Bloomington: Indiana University Publication. . 1976b. Folklore and Fakelore: Essays Toward a Discipline of Folk Studies. Cambridge, MA: Harvard University Press. . 1979. “The American Studies Type.” American Quarterly 31: 368-71.

Edwards, Jason. 2016. "Rhetorical Criticism." Encyclopedia of American Studies, ed. Simon J. Bronner. http://eas-ref.press.jhu.edu/view?aid=806. Accessed August 16, 2017. ., and David Weiss, eds. 2011. Rhetoric of American Exceptionalism. Jefferson, NC:

McFarland.

Elliott, Emory. 2007. "Diversity in the United States and Abroad: what Does It Mean When American Studies is Transnational.” American Quarterly 59: 1-22.

Fischer, Walther. 1951. "Die Amerikanistik im gegenwärtigen Universitätslehrplan und in den 
Prüfungsordnungen der deutschen Länder." Neuphilologische Zeitschrift 3: 412-14.

. 1955. "The Establishment and the Aims of the 'German Society for American Studies' ('Deutsch Gesellschaft für Amerikastudien')." Newsletter of the European Association for American Studies 1: 7-10.

Fishwick, Marshall, and Ray B. Browne, eds. 1970. Icons of Popular Culture. Bowling Green, OH: Bowling Green University Popular Press.

Fluck, Winifried. 2016. “American Studies in Germany." In Encyclopedia of American Studies, ed. Simon J. Bronner. Baltimore: Johns Hopkins University Press. http://eas-ref.press.jhu.edu/view? aid=783. Accessed August 23, 2017.

Fuller, Randall. 2006. "Errand into the Wilderness: Perry Miller as American Scholar." American Literary History 18: 102-28.

Gillman, Susan Kay. 2005. “The New, Newest Thing: Have American Studies Gone Imperial?” American Literary History 17: 196-214.

Gray, Richard. 2015. A History of American Poetry. Malden, MA: Wiley Blackwell.

Hilbish, D. Melissa. 1993. “Individual Member Survey 1990-91: Summary of Findings.” American Studies Association Newsletter 16 (September), 4-7.

Hinds, Harold E., Jr. Marilyn F. Motz, and Angela M.S. Nelson, eds. 2006. Popular Culture Theory and Methodology: A Basic Introduction. Madison: University of Wisconsin Press.

Hölbling, Walter W. 2005. “American Studies in Europe: Today and Tomorrow." American Studies Association Newsletter 28 (1): 15-17.

Jacobs, Jerry A. 2013. “American Studies: A Case Study of Interdisciplinarity.” PSC Working Paper Series PSC 13-08, Population Studies Center, University of Pennsylvania. http:// repository.upenn.edu/cgi/viewcontent.cgi?article=1049\&context=psc_working_papers Jacobson, William A. 2013. "List of Universities Rejecting Academic Boycott of Israel (Update250!)." Legal Insurrection (December 22). http://legalinsurrection.com/2013/12/list-ofuniversities- rejecting-academic-boycott-of-israel/. Accessed May 23, 2017.

Jaidka, Manju. 2017. “International American Studies Association (IASA)." In Encyclopedia of American Studies, ed. Simon J. Bronner (Baltimore: Johns Hopkins University Press). http://easref.press.jhu.edu/view?aid=874. Accessed August 23, 2017.

Jones, Howard Mumford. 1964. O Strange New World: American Culture, The Formative Years. New York: Viking Press.

. 1979. Howard Mumford Jones: An Autobiography. Madison: University of Wisconsin Press.

Kaplan, Amy. 2005. “A Call for a Truce.” American Literary History 17: 141-47. , and Donald E. Pease, eds. 1994. Cultures of United States Imperialism. Durham: Duke University Press. and Donald E. Pease, eds. 1993. Cultures of United States Imperialism. Durham: Duke University Press.

Klein, Julie Thompson. 1999. Mapping Interdisciplinary Studies: The Academy in Transition. Washington, D.C.: Association of American Colleges and Universities. http://files.eric.ed.gov/ fulltext/ED430437.pdf. Accessed August 16, 2017.

Kroes, Rob. 1987. “Americanistics in the Netherlands.” American Studies International 25: 56-65. 
Küchler, Uwe. 2017. "The Learning and Teaching of American Studies." In Approaches to American Cultural Studies, ed. Anje Dallmann, Eva Boesenberg, and Martin Klepper, 23-34. New York: Routledge.

Kuhn, Thomas S. 1970. The Structure of Scientific Revolutions. Chicago: University of Chicago Press.

Kulik, Gary. 2013. "The Shame of the American Studies Association." History News Network. (December 23). https://historynewsnetwork.org/article/154299. Accessed March 5, 2018.

Kupfer, Charles. 2016. “American Studies: A Sad Tale of Academic Decline.” James G. Martin Center for Academic Renewal, https://www.jamesgmartin.center/2016/12/american-studies-sad-taleacademic-decline/.

Lears, T. J. Jackson. 1985. "The Concept of Cultural Hegemony: Problems and Possibilities.” American Historical Review 90: 567-93.

Lee, Benjamin. 1995. “Critical Internationalism.” Public Culture 7: 559-92.

Lenz, Günter H. 2017. A Critical History of the New American Studies, 1970-1990, ed. Reinhard Isensee, Klaus J. Milich, Donald E. Pease, and John Carlos Rowe. Hanover, NH: Dartmouth College Press.

Lewis, George H., ed. 1972. Side-Saddle on the Golden Calf: Social Structure and Popular Culture in America. Pacific Palisades, CA: Goodyear.

Lipset, Seymour Martin, and Gary Marks. 2000. It Didn't Happen Here: Why Socialism Failed in the United States. New York: W. W. Norton.

Lipsitz, George. 2009. American Studies in a Moment of Danger. Minneapolis: University of Minnesota Press.

Marx, Leo. 2003-2004. “Believing in America.” Boston Review (December-January). http:// bostonreview.net/archives/BR28.6/marx.html. Accessed August 16, 2017. . "On Recovering the 'Ur' Theory of American Studies." American Literary History 17: $118-34$.

Mead, R.O., Sigmund Skard, and D.R. Wightman. 1955. "American Studies Conference in Salzburg 1954." Newsletter of the European Association for American Studies 1: 4-7.

Mechling, Jay. 1989. "Richard M. Dorson and the Emergence of the New Class in American Folk Studies." Journal of Folklore Research 26: 27-34.

, Robert Merideth, and David Wilson. 1973. “American Culture Studies: The Discipline and the Curriculum." American Quarterly 25: 363-89.

Miller, Perry. 1956. Errand into the Wilderness. Cambridge, MA: Harvard University Press.

Montenyohl, Eric. 1996. “Divergent Paths: On the Evolution of 'Folklore' and 'Folkloristics.”' Journal of Folklore Research 33: 232-35.

Moran, Joe. 2002. Interdisciplinarity. London: Routledge.

Mullen, Bill V. 2015. "Throwing Stones in Glass Houses: The ASA and the Road to Academic Boycott." American Quarterly 67: 1075-83.

Murphey, Murray G. 1999. “American Civilization as a Discipline?” American Studies 40: 5-21. . 2001. "Perry Miller and American Studies." American Studies 42: 5-18.

Musher, Sharon Ann. 2015. "The Closing of the American Studies Association's Mind." In The Case Against Academic Boycotts of Israel, ed. Cary Nelson and Gabriel Noah Brahm, 105-18. Chicago: MLA Members for Scholars' Rights. 
Nye, Rusel. 1970. The Unembarrassed Muse: The Popular Arts in America. New York: Dial Press.

Office of the President. 2013. "Statement on ASA Resolution." Harvard University President News. http://www.harvard.edu/president/news/2013/statement-on-asa-resolution. Accessed June 13, 2017.

Oppermann, Matthias. 2011. American Studies in Dialogue: Radical Reconstructions between Curriculum and Cultural Critique. Frankfurt am Main: Campus.

2017. "History of American Studies: From Its Emergence to Transnational Studies." In Approaches to American Cultural Studies, ed. Antje Dalmann, Eva Boesenberg, and Martin Klepper, 13-22. New York: Routledge.

Organizations and Universities that Have Condemned the American Studies Association's Academic Boycott of Israel." 2017. AMCHA Initiative. https://amchainitiative.org/organizationsuniversities-condemned-american-studies-associations-academic-boycott-israel/. Accessed December 7, 2017.

Parrington, Vernon Louis. 1927. Main Currents in American Thought. New York: Harcourt, Brace.

Pease, Donald E., and Robyn Wiegman, eds. 2010. The Futures of American Studies. Durham, NC: Duke University Press.

Pells, Richard. 2016. "The Decline of American Studies.” Chronicle of Higher Education (June 5). http://www.chronicle.com/article/The-Decline-of-American/236667

"Pre-Convention Day for American Studies Program Directors." 1993. American Studies Association Newsletter 16 (May), 9.

Radway, Janice. 1999. "What's in a Name? Presidential Address to the American Studies Association, 20 November, 1998." American Quarterly 51: 1-32. ,ed. 2009. American Studies: An Anthology. Malden, MA: Wiley-Blackwell.

Roark, James L, Michael P. Johnson; Patricia Cline Cohen, Sarah Stage, and Susan M. Hartmann. 2017. Understanding the American Promise: A History. Boston: Bedford/St. Martins.

Rourke, Constance. 1931. American Humor: A Study of the National Character. New York: Doubleday. 1942. The Roots of American Culture, And Other Essays, ed. Van Wyck Brooks. New York: Harcourt, Brace.

Rowe, John Carlos, ed. 2000. Post-Nationalist American Studies. Berkeley, CA: University of California Press.

. 2002a. The New American Studies. Minneapolis: University of Minnesota Press. .2002b. "Postnationalism, Globalism, and the New American Studies." In The Futures of American Studies, ed. Donald E. Pease and Robyn Wiegman, 167-82. Durham, NC: Duke University Press.

Rubin, Joan Shelley. 1980. Constance Rourke and American Culture. Chapel Hill: University of North Carolina Press.

Sasaki, Takashi. 2005. "Repositioning American Studies.” American Studies Association Newsletter 28 (1): 14 .

Schmidt, Peter. 2014. "Backlash Against Israel Boycott Throws Academic Association on Defensive.” New York Times (January 5). https://www.nytimes.com/2014/01/06/us/backlashagainst-israel-boycott-throws-academic-association-on-defensive.html. 
Shank, Barry. 1997. "The Continuing Embarrassment of Culture: From the Culture Concept to Cultural Studies.” American Studies 38: 95-116.

Skard, Sigmund. 1955a. "Suggested Topics for Research by European Scholars." Newsletter of the European Association for American Studies 1: 11-14.

1955b. "Words of Introduction." Newsletter of the European Association for American Studies $1: 3-4$.

Smith, Henry Nash. 1957. “Can ‘American Studies’ Develop a Method?” American Quarterly 9: 197-208. Society of Americanists. 2016. “The Society of Americanists to Launch Next Spring!” (September 11).

Society of Americanists: A Coalition of Persons, Organizations, and Programs Devoted to the Study of the United States. http://americanist.net. Accessed June 13, 2017.

Storey, John, ed. 2009. Cultural Theory and Popular Culture: A Reader. Harlow, UK: Pearson.

Strunz, Gisela. 1999. American Studies oder Amerikanistik? Die deutsche Amerkawissenschaft und die Hoffnung auf Erneuerung der Hochschulen unter der politischen Kultur nach 1945. Opladen: Leske \& Budrich.

Sykes, Richard E. 1963. "American Studies and the Concept of Culture: A Theory and Method." American American Quarterly 15: 253-70.

“Task Forces.” 2014. American Studies Association website. https://theasa.net/about/advocacy/ task-forces. Accessed May 23, 2017.

Tate, Cecil F. 1973. The Search for a Method in American Studies. Minneapolis: University of Minnesota Press.

Walker, Robert H. 1958. American Studies in the United States: A Survey of College Programs (Baton Rouge: Louisiana State University Press.

. 1971. "Report from the President." American Quarterly 23: 259-64.

Walsh, Michael. 2015. The Devil's Pleasure Palace: The Cult of Critical Theory and the Subversion of the West. New York: Encounter Books.

Watts, Steven. 1991. "The Idiocy of American Studies: Poststructuralism, Language, and Politics in the Age of Self-Fulfilment." American Quarterly 43: 625-60.

Whitman, Walt. Leaves of Grass. Philadelphia: David McKay.

Winks, Robin W. 1976. "The American Studies Bicentennial Project.” American Studies International 15: 9-18.

Wise, Gene. 1979a. “An American Studies Calendar.” American Quarterly 31: 407-47. . 1979b "'Paradigm Dramas' in American Studies: A Cultural and Institutional History of the Movement." American Quarterly 31: 293-337.

Wolfe, Alan. 2003. “Anti-American Studies.” New Republic (February 10), 25-31.

Wood, Peter. 2013. “ASA and the Politicization of Academe." Minding the Campus: Reforming Our Universities. http://www.mindingthecampus.com/2013/12/asa_and_the_politicization_of_/. Accessed June 13, 2017.

Wright, Richard. 1941. 12 Million Black Voices: A Folk History of the Negro in the United States. New York: Viking Press. 


\section{NOTES}

1. The Department of American Culture at the University of Michigan claims on its website in 2017 that it "was the first formal academic program in American studies, and that, from its start in 1935, it looked beyond the confines of history and literature" (https://lsa.umich.edu/ac/about-us/department-history.html). Harvard's site flatly declares "we are the oldest American Studies program in the country" (americanstudies.fas.harvard.edu). Gene Wise in his American Studies "Calendar" (1979) lists the Harvard program as the first Ph.D. program in 1936, and cites the precedent in 1933 of a course at Harvard co-taught by F.O. Matthiessen and Perry Miller. Wise also credits A. Whitney Griswold's Yale dissertation "The American Cult of Success" (1933) as "one of the first American Studies Ph.D.'s in country" (415).

2. Kaplan was using exceptionalism pejoratively to indicate the view she rejected that America was superior to, and different from, other nations in the world. The Americanists tended not to use the term, which has a source in Karl Marx's view that the United States, alone among industrial societies, lacks a significant socialist movement or labor party (Lipset and Marks 2000). The issue for many Americanists was the ways that particular American historical and social conditions influenced distinctive cultural development in the United States much as they had for other countries. Long acknowledging cultural, social, and geographic diversity, Dorson and others asked about the themes and ideas that connected Americans. See Edwards and Weiss 2011.

3. The Society of Americanists was launched at a conference on March 31, 2017, in Harrisburg, Pennsylvania. According to its website ( https://sites.psu.edu/ americanist/) The Society of Americanists (SOA) is a coalition of persons, organizations, and academic programs devoted to the study of the United States. SOA has its purpose fostering integrated studies of American history, society, arts, and culture in all their aspects; providing a forum for discussion of scholarly and professional issues among its members, including an annual conference and communications; and promotion of the profession of Americanists devoted to the study of the United States in a global context. Its distinctive niche in the organizational landscape of learned, professional societies in American Studies is to represent the discipline and profession of Americanists and advance analytical approaches to the research and interpretation of the United States" (Society of Americanists 2016).

4. The Zeitschrift für Anglistik und Amerikanistik [Journal of English and American Studies] published by De Gruyter proclaims its scope as "the entire spectrum of English and American language, literature and culture" (https://www.degruyter.com/view/j/ zaa). Arbeiten aus Anglistik und Amerikanistik [Work in English and American Studies] published by Narr Francke Attempto Verlag is devoted to einzelnen Teildisziplinen, or the individual disciplines of English and American studies. Degrees are offered in Amerikanistik at universities such as the University of Graz, which announces its goal of "teaching and research to the study of the overall cultural and social development of the U.S.A." (https://amerikanistik.uni-graz.at/en/the-department/). To be sure, Amerikastudien/American Studies is the official journal of the German Association for American Studies and has featured innovative, inclusive studies of the United States in a global perspective (http://www.amerikastudien.de/quarterly/). My point, however, is that the term Americanistics more clearly designates the analytical inter-cultural 
approach to the study of the United States and could be the keyword that avoids problems in the field with a diffuse, politicized "American Studies."

\section{ABSTRACTS}

Using the life-course metaphor in Richard M. Dorson's landmark address "The Birth of American Studies" in Warsaw on the occasion of forty years since the start of the groundbreaking Harvard program in American Studies, this essay questions whether American Studies in the forty years afterwards suffered a fatal malaise. It applies the analytical approach of historiographer Gene Wise to identify "representative acts" that mark paradigm dramas resulting from tension in holding together an interdisciplinary field subject to schism and displacement. The essay posits that the American Studies movement as it was conceptualized within the American Studies Association in the United States went into decline in the late twentieth century, largely because of the association's inability, or unwillingness, to resolve differences between "Americanist" research-based scholars, many international, working within an American Studies tradition identified by Dorson and those coming to it from outside American Studies supposedly following "critical" thought. The critical school came to be dominant in the American Studies Association with a paradoxical attitude undermining the very subject, and organization, that it purports to promote. Looking at the work of American Studies programs and organizations beyond the American Studies Association, the essay suggests that it is possible to revitalize American Studies on the model of "Americanistics" sustained primarily in European centers and associations.

\section{AUTHOR}

\section{SIMON J. BRONNER}

Simon J. Bronner is distinguished professor emeritus of American Studies and folklore at the Pennsylvania State University, Harrisburg, where he was the founding director of the American Studies doctoral program. He has also taught at Leiden University (Netherlands), Osaka University (Japan), Harvard University (USA), Dickinson College (USA), and University of California, Davis (USA).He is the author and editor of over forty books, including most recently Pennsylvania Germans: An Interpretive Encyclopedia (2017), Youth Cultures in America (2016), Campus Traditions (2012), and Explaining Traditions (2011). He served as editor of the Encyclopedia of American Studies online until 2016 and in addition to currently editing the Oxford Handbook of American Folklore and Folklife Studies now edits book series on Material Worlds for the University Press of Kentucky and Folklore and Ethnology for Lexington Books. His recent awards include the Mary C. Turpie Prize from the American Studies Association for teaching, advising, and program development in American Studies; Kenneth Goldstein Lifetime Achievement Award from the American Folklore Society for academic leadership; and Lifetime Achievement Medal from the American Folklore Society for scholarship in children's folklore. 